\title{
PENGARUH KOMPENSASI DAN DISIPLIN KERJA TERHADAP KINERJA KARYAWAN PADA PT. BAKRIE CONSTRUCTION BOJONEGARA
}

\author{
Syifa Firdiani ${ }^{1}$, Furtasan Ali Yusuf ${ }^{2}$, Basrowi $^{3}$ \\ ${ }^{1,2,3}$ Universitas Bina Bangsa, Indonesia \\ Syifafirdiani28@gmail.com
}

\begin{abstract}
ABSTRAK
Sumber daya manusia dalam suatu perusahaan sangat mempengaruhi kinerja perusahaan, hal ini dapat dilihat dari kinerja yang dihasilkan oleh karyawan dalam perusahaan. Pemberian kompensasi yang sesuai atas pekerjaannya dapat memacu semangat karyawan untuk bekerja lebih baik dari waktu ke waktu, Disiplin kerja sangat mempengaruhi kinerja karyawan, hal ini disebabkan karena disiplin merupakan bentuk-bentuk latihan bagi karyawan dalam melaksanakan aturan-aturan perusahaan, semakin disiplin karyawan maka semakin tinggi juga produktivitas kerja karyawan dan kinerja pada perusahaan. Penelitian ini bertujuan untuk mengetahui pengaruh kompensasi dan disiplin kerrja terhadap kinerja karyawan pada PT. Bakrie Construction Bojonegara baik secara parsial maupun seecara simultan. Metode penelitian yang digunakan adalah metode pendekatan kuantitatif dengan data yang digunakan berupa data primer dan data sekunder. Dengan total populasi yang digunakan dalam penelitian ini adalah sebanyak 34 karyawan divisi engineering. Penentuan sampel menggunakan teknik sampling jenuh dengan sampel sebanyak 34 karyawan divisi engineering. Berdasarkan hasil pengujian hipotesis dapat diambil kesimpulan bahwa terdapat pengaruh antara kompensasi dan disiplin kerja terhadap kinerja karyawan pada PT. Bakrie Constuction Bojonegara secara parsial maupun simultan.
\end{abstract}

Kata Kunci : Kinerja Karyawan, Kompensasi, Disiplin Kerja

\begin{abstract}
Human resources in a company greatly affect the performance of the company, this can be seen from the performance produced by employees in the company. Providing appropriate compensation for their work can spur employees' enthusiasm to work better from time to time. Work discipline greatly affects employee performance, this is because discipline is a form of training for employees in implementing company rules, the more disciplined employees are, the more disciplined employees will be. also high employee work productivity and performance at the company. This study aims to determine the effect of compensation and work discipline on employee performance at PT. Bakrie Construction Bojonegara either partially or simultaneously. The research method used is a quantitative approach with the data used in the form of primary data and secondary data. With the total population used in this study were 34 employees of the engineering division. Determination of the sample using saturated sampling technique with a sample of 34 employees of the engineering division. Based on the results of hypothesis testing, it can be concluded that there is an influence between compensation and work discipline on employee performance at PT. Bakrie Construction Bojonegara partially or simultaneously.
\end{abstract}

Keywords: Employee Performance, Compensation, Work Discipline 


\section{PENDAHULUAN}

Setiap perusahaan yang didirikan memiliki tujuan yang hendak dicapai. Tujuan perusahaan dapat tercapai dengan adanya peran sumber daya manusia sebagai faktor sentral yang mengatur jalannya perusahaan. Perusahaan dibuat berdasarkan visi untuk kepentingan manusia dan dalam pelaksanaan misinya dikelola dan diurus oleh manusia. Manusia dikatakan sebagai sumber daya penting karena bagaimana pun canggihnya teknologi yang ada, manusia merupakan pelaku utama dalam teknologi itu sendiri. Kinerja pada umumnya dapat di artikan sebagai kesuksesan seseorang dengan melaksanakan suatu pekerjaan, kinerja yang baik adalah kinerja yang mengikuti tata cara atau prosedur sesuai standar yang telah di tetapkan.

Kinerja merupakan suatu proses tentang bagaimana pekerjaan berlangsung untuk mencapai hasil kerja. Kinerja individu yang baik dapat meningkat apabila ada kesesuaian antara pekerjaan dan kemampuan kemampuan kinerja individu yang baik dapat meningkat apabila ada kesesuaian antara pekerjaan dan kemampuan. Istilah kinerja sering di dengar dan sangat penting bagi sebuah perusahaan dalam mencapai tujuannya. Dalam kaitannya dengan pengembangan sumber daya manusia, kinerja seseorang pegawai sangat dibutuhkan untuk mencapai kinerja bagi pegawai itu sendiri dan itu juga untuk keberhasilan perusahaan.

Kinerja adalah hasil pekerjaan yang dicapai karyawan berdasarkan persyaratan persyaratan pekerjaan. Kinerja karyawan adalah hasil kerja yang dalam kualitas dan kuantitas yang di dapatkan karyawan dalam mendukung tercapainya tujuan organisasi. Hasil dari pekerjaannya tersebut memberikan umpan balik untuk dirinya sendiri sehingga selalu akan melakukan pekerjaan dengan baik dan menghasilkan produktivitas yang tinggi.

Kinerja karyawan merupakan hasil dari usaha yang dikerjakan seseorang dengan kemampuan serta penilaian kerja yang telah diberikan kepadanya untuk mencapai hasil yang optimal. Produktivitas seseorang dalam melakukan suatu pekerjaan, pelatihan, dan motivasi yang diterima.

Rendahnya suatu kinerja karyawan dalam perusahaan merupakan suatu masalah yang banyak ditemui dalam perusahaan. Rendahnya kinerja menjadi salah satu penyebab yang mencerminkan dari ketidakberhasilan perusahaan dalam mengembangkan karyawan yang sesuai dengan standar perusahaan guna mencapai tujuan perusahaan, ini akan menjadi suatu ancaman serius bagi perusahaan apabila kinerja karyawan tidak segera diperbaiki. Kompensasi merupakan segala sesuatu yang diterima oleh para karyawan sebagai tanda balas jasa untuk kerja mereka. Setiap perusahaan memiliki perbedaan sistem kompensasi, sistem kompensasi disesuaikan dengan visi, misi dan tujuannya. Kompensasi yang sesuai dengan keinginan 
Prosiding The 1st National Conference on Applied Business, Education, \& Technology (NCABET)"

Unversitas Bina Bangsa 2021

DOI Article : 10.46306/ncabet.v1i1.37

karyawan atas pekerjaannya dapat memacu semangat karyawan untuk bekerja lebih baik dari waktu ke waktu, sehingga memberikan pengaruh positif bagi peningkatan hasil kerja karyawan.

Kompensasi adalah kesepakatan antara karyawan dan pemilik. Kompensasi adalah kebutuhan hidup. Pembayaran diterima dari pekerjaan yang dilakukan atas nama orang yang mendapatkan pekerjaan. Kompensasi adalah salah satu bagian terpenting dari arus kas. Kompensasi sebagian besar besarannya merupakan setengah dari arus kas perusahaan. Namun di sektor jasa jumlahnya lebih dari setengah. Kompensasi adalah hal utama untuk menarik karyawan dan memotivasi karyawan untuk meningkatkan kinerja.

Kompensasi adalah imbalan jasa atau balas jasa yang diberikan oleh organisasi kepada para tenaga kerja karena tenaga kerja tersebut telah memberikan sumbangan tenaga dan pikiran demi kemajuan organisasi guna mencapai tujuan yang telah ditetapkan. Kompensasi merupakan semua bentuk pembayaran atau reward kepada karyawan yang berasal dari hasil pekerjaan mereka. Kompensasi adalah semua pendapatan yang berbentuk uang, barang langsung atau tidak langsung yang diterima karyawannya sebagai imbalan atas jasa yang diberikan kepada perusahaan

Diketahui bahwa kompensasi tidak saja diberikan dalam bentuk finansial, tetapi dapat juga berupa bukan uang/material/benda. Arti penting kompensasi kepada organisasi adalah sebagai upaya mempertahankan dan meningkatkan kesejahteraan pegawai di dalamnya. Pemberian kompensasi oleh organisasi sudah di atur sedemikian rupa sehingga menjadikan sistem yang lebih baik di sebuah perusahaan. Kompensasi yang sesuai dengan keinginan karyawan atas pekerjaannya dapat memacu semangat karyawan untuk bekerja lebih baik dari waktu ke waktu, sehingga memberikan pengaruh positif bagi peningkatan hasil kerja karyawan.

Disiplin kerja merupakan faktor yang dapat mempengaruhi kinerja karyawan. Disiplin kerja sangat mempengaruhi kinerja karyawan, hal ini disebabkan karena disiplin merupakan bentuk - bentuk latihan bagi karyawan dalam melaksanakan aturan - aturan perusahaan. Kedisiplinan merupakan fungsi operatif manajemen sumber daya manusia yang terpenting karena semakin baik disiplin pegawai, semakin tinggi prestasi kerja yang dapat dicapainya.

Disiplin pada hakikatnya mencerminkan besarnya tanggung jawab seseorang terhadap tugas yang diberikan kepadanya. Disiplin kerja diartikan jika karyawan selalu datang dan pulang pada tepat waktunya, mengerjakan semua pekerjaannya dengan baik dan tepat waktu, melaksanakan perintah atasan.

Disiplin merupakan sikap seseorang atau kelompok yang berniat untuk mengikuti aturan - aturan yang telah ditetapkan. Dalam kaitannya dengan pekerjaan, pengertian disiplin kerja adalah suatu sikap dan tingkah laku yang menunjukan ketaatan karyawan terhadap 
Prosiding The 1st National Conference on Applied Business, Education, \& Technology (NCABET)"

Unversitas Bina Bangsa 2021

DOI Article : 10.46306/ncabet.v1i1.37

peraturan organisasi. Disiplin merupakan tindakan manajemen untuk mendorong para anggota organisasi memenuhi tuntutan berbagai ketentuan tersebut. Kedisiplinan adalah sebuah bentuk rasa tanggung jawab dan kewajiban karyawan untuk mentaati peraturan yang telah di tetapkan.

Seorang karyawan yang memiliki tingkat kedisiplinan yang tinggi akan tetap bekerja dengan baik walaupun tanpa diawasi oleh atasan. Seorang karyawan yang disiplin tidak akan melakukan hal-hal lain yang tidak ada hubungannya dengan pekerjaannya. Oleh karena itu, karyawan yang disiplin akan memiliki kinerja yang baik dibandingkan dengan karyawan yang malas karena waktu kerja digunakan untuk melaksanakan pekerjaan sesuai dengan target. Sulit bagi karyawan untuk produktif, mengembangkan dan meningkatkan kinerjanya sesuai dengan motivasi dan pengalaman kerja pada khususnya manakala mereka tidak disiplin. Selain itu juga sulit untuk menciptakan dan mencapai tujuan organisasi yang optimal secara umum manakala mayoritas karyawannya tidak disiplin.

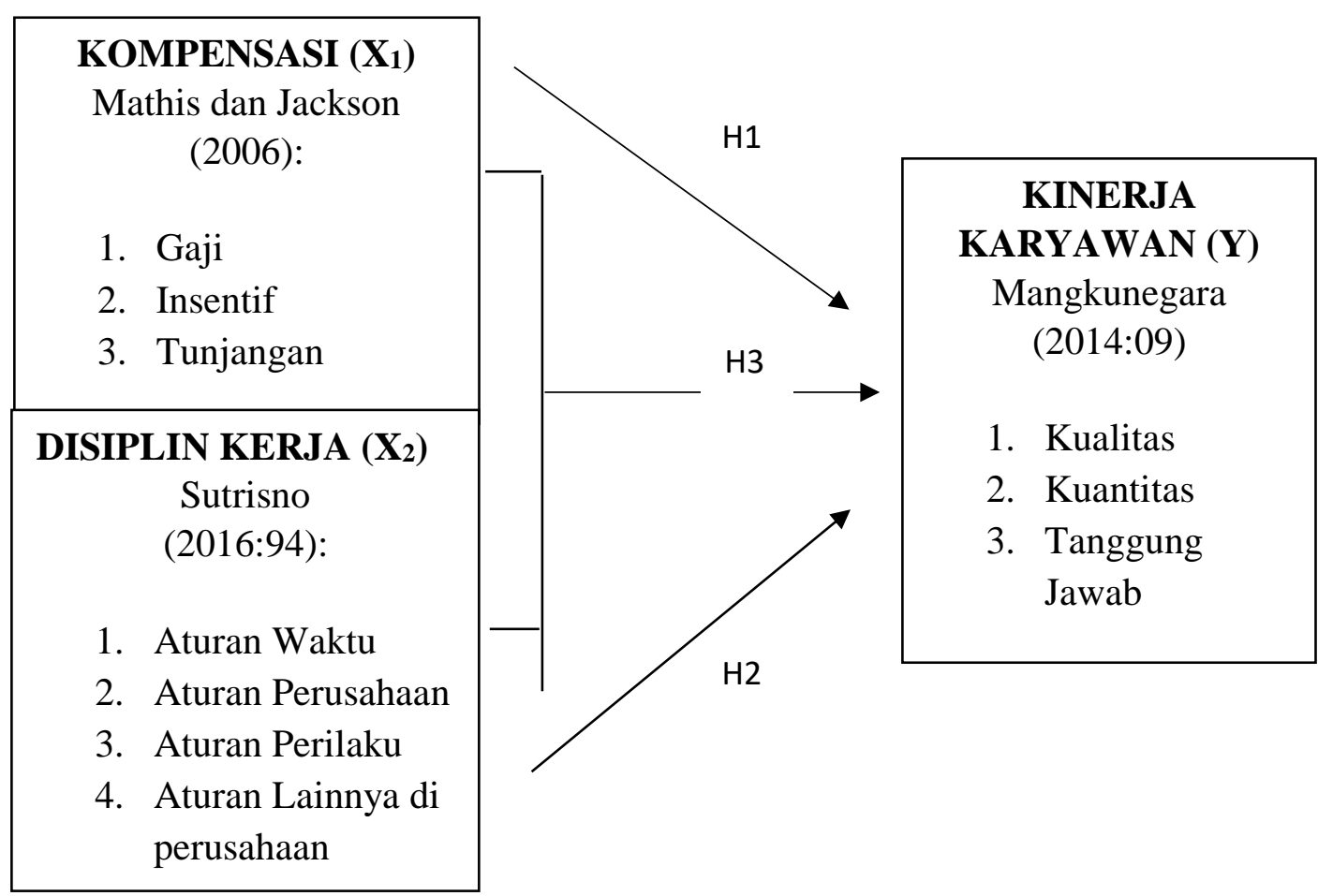

Gambar 1 Kerangka Berfikir Penelitian

\section{METODE PENELITIAN}

Metode penelitian adalah cara ilmiah untuk mendapatkan data dengan tujuan dan kegunaan tertentu. Metode yang digunakan dalam penelitian ini adalah metode deskriptif dan metode asosiatif. Metode deskriptif adalah suatu metode penelitian yang bertujuan untuk menggambarkan dan menjelaskan keadaan yang ada di PT. Bakrie Construction, berdasarkan fakta yang dikumpulkan kemudian disusun secara sistematis yang selanjutnya dianalisis untuk mendapatkan kesimpulan. Metode asosiatif yaitu dengan melakukan studi kasus yang 
Prosiding The 1st National Conference on Applied Business, Education, \& Technology (NCABET)"

Unversitas Bina Bangsa 2021

DOI Article : 10.46306/ncabet.v1i1.37

merupakan suatu metode yang bertujuan untuk mengamati aspek - aspek tertentu secara lebih spesifik untuk memperoleh data yang sesuai dengan tujuan penelitian

\section{Waktu dan Tempat}

Penelitian ini berlangsung selama empat bulan, terhitung mulai tanggal 03 bulan Mei 2021 sampai dengan tanggal 16 bulan September 2021. Penelitian ini dilakukan pada karyawan PT. Bakrie Construction yang berlokasi di RT.001, RW. 01, Sumuranja, Puloampel, Cilegon, Banten, 42456.

\section{Populasi dan Sampel}

Populasi pada penelitian ini sebanyak 34 karyawan divisi Engineering. Sampel yang digunakan dalam penelitian ini yaitu divisi engineering sebanyak 34 karyawan. Karena sampel relatif kecil maka dari itu menggunakan teknik sampling jenuh.

\section{HASIL DAN PEMBAHASAN}

\section{Koefesien Determinasi}

Uji koefesien determinasi pada intinya mengukur seberapa jauh kemampuan model dalam menerangkan variabel - variabel. Uji koefesien determinasi ini digunakan karena dapat menjelaskan kebaikan dari model regresi dalam variabel dependent. Semakin tinggi nilai koefesien determinasi maka akan semakin baik pula kemampuan variabel independent dalam menjelaskan variabel dependent. Nilai koefesien determinasi adalah antara nol dan satu. Nilai $\mathrm{R}$ Square yang kecil berarti kemampuan variabel - variabel independent dalam menjelaskan variabel - variabel dependent amat terbatas.

Tabel 1 Hasil Uji Koefesien Determinasi Berganda Variabel Kompensasi $\left(\mathrm{X}^{1}\right)$ dan Disiplin Kerj $\left(\mathrm{X}^{2}\right)$

Model Summary

\begin{tabular}{|l|r|r|r|r|}
\hline Model & \multicolumn{1}{|c|}{$\mathrm{R}$} & R Square & $\begin{array}{c}\text { Adjusted R } \\
\text { Square }\end{array}$ & $\begin{array}{c}\text { Std. Error of the } \\
\text { Estimate }\end{array}$ \\
\hline 1 & $.649^{\mathrm{a}}$ & .422 & .384 & 1,447 \\
\hline
\end{tabular}

a. Predictors: (Constant),Kompensasi, Disiplin_Kerja

Sumber : Data Hasil Olah SPSS Versi 25

Dapat diketahui bahwa Kompensasi $\left(\mathrm{X}_{1}\right)$ dan Disiplin Kerja $\left(\mathrm{X}_{2}\right)$ berkontribusi sebesar 42,1\% terhadap Kinerja Karyawan (Y), sedangkan sisanya 57,9\% dipengaruhi oleh faktor lain yang tidak dijelaskan dalam penelitian ini.

\section{Uji t}


Prosiding The 1st National Conference on Applied Business, Education, \& Technology (NCABET)"

Unversitas Bina Bangsa 2021

DOI Article : $10.46306 /$ ncabet.v1i1.37

Pengujian hipotesis dilakukan untuk mengetahui apakah variabel tersebut signifikan atau tidak. Maka, untuk mengetahui hipotesis tersebut maka dilakukan dengan Uji-t yang bertujuan untuk melihat signifikan atau tidaknya variabel bebas dalam model regresi variabel independen secara parsial, berpengaruh signifikan terhadap variabel dependen, yaitu seperti ditunjukan tabel di bawah ini :

Tabel 2 Uji Hipotesis Secara Parsial

Coefficients $^{\mathbf{a}}$

\begin{tabular}{|c|c|c|c|c|c|}
\hline \multirow{2}{*}{ Model } & \multicolumn{2}{|c|}{$\begin{array}{l}\text { Unstandardize } \\
\text { d Coefficients }\end{array}$} & \multirow{2}{*}{$\begin{array}{c}\begin{array}{c}\text { Standardized } \\
\text { Coefficients }\end{array} \\
\text { Beta }\end{array}$} & \multirow{2}{*}{$\mathbf{T}$} & \multirow{2}{*}{ Sig. } \\
\hline & B & $\begin{array}{c}\text { Std. } \\
\text { Error }\end{array}$ & & & \\
\hline $1 \quad$ (Constant) & 1,144 & 4,373 & & .262 & .795 \\
\hline $\begin{array}{l}\text { Kompensasi } \\
\text { (X1) }\end{array}$ & .448 & .155 & .418 & 2,901 & .007 \\
\hline $\begin{array}{l}\text { Disiplin } \\
\text { Kerja (X2) }\end{array}$ & .267 & .101 & .382 & 2,652 & .013 \\
\hline
\end{tabular}

a. Dependent Variable: Kinerja Karyawan (Y)

Sumber : Data Hasil Olah SPSS Versi 25

Hasıl pengujıan hipotesis pertama $\left(\mathrm{H}_{1}\right)$ diketahuı sebesar 2,901 berarti nilai $t_{\text {hitung }}>t_{\text {tabel }}$ atau 2,901 >1,691 dengan taraf signifikansi $0,007<(\alpha) 0,05$ sehingga dapat disimpulkan bahwa $\mathrm{H}_{\mathrm{a}}$ diterima. Hasil pengujian hipotesis kedua $\left(\mathrm{H}_{2}\right)$ diketahui nilai $t_{\text {hitung }}>\mathrm{t}_{\text {tabel }}$ atau 2,652 $>1,691$ dengan taraf signifikansi $0,013<(\alpha) 0,05$, sehingga dapat disimpulkan bahwa $\mathrm{H}_{\mathrm{a}}$ diterima.

Uji f

Pengaruh Kompensasi $\left(\mathrm{X}_{1}\right)$ dan Disiplin Kerja $\left(\mathrm{X}_{2}\right)$ Terhadap Kinerja Karyawan $(\mathrm{Y})$ adalah sebagai berikut :

Tabel 3 Uji Hipotesis Simultan Dengan F-test

ANOVA ${ }^{\mathrm{a}}$

\begin{tabular}{|c|c|c|c|c|c|c|}
\hline & Model & $\begin{array}{c}\text { Sum of } \\
\text { Squares }\end{array}$ & Df & $\begin{array}{c}\text { Mean } \\
\text { Square } \\
\end{array}$ & $\mathbf{F}$ & Sig. \\
\hline \multirow{3}{*}{1} & Regression & 47,351 & 2 & 23,676 & 11,306 &, $000^{\mathrm{b}}$ \\
\hline & Residual & 64,914 & 31 & 2,094 & & \\
\hline & Total & 112,265 & 33 & & & \\
\hline
\end{tabular}

a. Dependent Variable: Kinerja Karyawan (Y)

b. Predictors: (Constant), Disiplin Keria (X2), Kompensasi (X1)

B Sumber: Data Hasil Olah SPSS Versi $25 \quad$ roleh nilai F hitung sebesar 11,306 hasil ini kemudian dibandingkan dengan $\mathrm{F}$ tabel. Dengan tingkat signifikasi $(\alpha)$ sebesar 5\% (0.05), dan df : $\mathrm{n}-\mathrm{k}-1=34-2-1=31$ maka diperoleh $\mathrm{F}$ tabel sebesar (3.28), karena nilai $\mathrm{F}$ 
Prosiding The 1st National Conference on Applied Business, Education, \& Technology (NCABET)"

Unversitas Bina Bangsa 2021

DOI Article : 10.46306/ncabet.v1i1.37

hitung $(11,306)>\mathrm{F}$ tabel , maka $H_{o}$ ditolak, sehingga dapat disimpulkan bahwa terdapat pengaruh yang positif dan signifikan secara simultan antara variabel Kompensasi $\left(\mathrm{X}_{1}\right)$ dan Disiplin Kerja $\left(\mathrm{X}_{2}\right)$ terhadap Kinerja Karyawan (Y). Dari output SPSS di atas diketahui nilai signifikansi sebesar 0,000. Karena nilai signifikansi $0,000<0,05$ sesuai dengan dasar pengambilan keputusan dalam Uji F maka dapat disimpulkan pula bahwa Kompensasi $\left(\mathrm{X}_{1}\right)$ dan Disiplin Kerja $\left(\mathrm{X}_{2}\right)$ secara simultan bersama - sama berpengaruh signifikan terhadap Kinerja Karyawan (Y).

\section{KESIMPULAN DAN SARAN}

\section{Kesimpulan}

Berdasarkan hasil anlisis dan pembahasan, tentang pengaruh Kompensasi dan Disiplin Kerja Terhadap Kinerja Karyawan pada PT. Bakrie Constructions, Bojonegara. Penulis menarik kesimpulan sebagai berikut :

1. Dari hasil Uji t diperoleh bahwa nilai t hitung variabel Kompensasi $\left(\mathrm{X}_{1}\right)$ sebesar 2,901 dan $t$ tabel sebesar 1,691, dengan tingkat signifikansi $0,007<(\alpha) 0,05$ dan nilai koefesien variabel kompensasi adalah 0,448 maka besarnya pengaruh kompensasi $\left(\mathrm{X}_{1}\right)$ terhadap kinerja karyawan (Y) adalah sebesar 44,8\%. Karena t hitung $(2,901)>1,691$ maka terdapat pengaruh yang positif dan signifikan antara Kompensasi $\left(\mathrm{X}_{1}\right)$ terhadap Kinerja Karyawan (Y) pada PT. Bakrie Construction, Bojonegara.

2. Dari hasil Uji t diperoleh bahwa nilai t hitung variabel Disiplin Kerja $\left(\mathrm{X}_{2}\right)$ sebesar 2,652 dan $t$ tabel sebesar 1,691, dengan tingkat signifikansi $0,013<(\alpha) 0,05$ dan nilai koefesien variabel disiplin kerja adalah 0,267 maka besarnya pengaruh disiplin kerja $\left(\mathrm{X}_{2}\right)$ terhadap kinerja karyawan $(\mathrm{Y})$ adalah sebesar $26,7 \%$. Karena t hitung $(2,652)>$ 1,691 maka terdapat pengaruh positif dan signifikan antara variabel disiplin kerja $\left(\mathrm{X}_{2}\right)$ terhadap kinerja karyawan (Y)

3. Dari hasil uji koefesien (R2) variabel kompensasi $\left(\mathrm{X}_{1}\right)$ dan disiplin kerja $\left(\mathrm{X}_{2}\right)$ secara simultan berkontribusi terhadap kinerja karyawan (Y) sebesar 0,422 atau 42,1\%. Berdasarkan hasil Uji f pengolahan SPSS versi 25 diperoleh nilai f hitung sebesar 11,306 dan $\mathrm{f}$ tabel sebesar $(3,28)$, dengan tingkat signifikansi $(\alpha)$ sebesar 5\% $(0,05)$. Karena $\mathrm{f}$ hitung memiliki nilai $(11,306)>\mathrm{f}$ tabel dan nilai signifikansi sebesar 0,000 $<0,05$ maka terdapat pengaruh yang positif dan signifikan secara simultan antara variabel Kompensasi $\left(\mathrm{X}_{1}\right)$ dan Disiplin Kerja $\left(\mathrm{X}_{2}\right)$ terhadap Kinerja Karyawan $(\mathrm{Y})$.

\section{Saran}


Prosiding The 1st National Conference on Applied Business, Education, \& Technology (NCABET)"

Unversitas Bina Bangsa 2021

DOI Article : 10.46306/ncabet.v1i1.37

Berdasarkan pada kesimpulan dan implikasi di atas, maka saran dari peneliti adalah sebagai berikut :

1. Berdasarkan hasil penelitian pada karyaawan PT. Bakrie Construction Bojonegara disarankan pimpinan sebaiknya lebih memperhatikan dalam pemberian kompensasi kepada karyawannya karena dengan pemberian kompensasi yang teratur dapat meningkatkan kinerja karyawannya.

2. Berdasarkan hasil penelitian dan penilaian pada karyawan PT. Bakrie Construction, Bojonegara.Disarankan pimpinan harus memperhatikan tingkat kedisiplinan karyawannya dengan tegas agar setiap karyawan yang berada pada perusahaan memiliki tanggung jawab dan upaya untuk mencapai atau melebihi standar kerja yang telah ditetapkan. Pemberian sanksi yang tepat juga berguna untuk meningkatkan ketertiban perusahaan. Salah satu cara yang dapat ditempuh oleh perusahaan untuk meningkatkan kewaspadaan tinggi dalam bekerja oleh karyawan yaitu setiap karyawan haruslah selalu teliti dan tidak mangkir dalam bekerja guna untuk menghindari dari kemungkinan kesalahan yang akan dilakukan karyawan dalam bekerja, sehingga dapat lebih efektif dan efesien.

3. Bagi peneliti selanjutnya yang tertarik untuk melanjutkan penelitian ini bisa digunakan sebagai bahan perbandingan dan referensi untuk melakukan penelitian dan juga sebagai bahan pertimbangan untuk lebih memperdalam penelitian selanjutnya. Dan di harapkan untuk peneliti selanjutnya mengobservasikan terlebih dahulu mengenai permasalahan yang terdapat pada PT. Bakrie Construction, Bojonegara dengan menambahkan variabel lain yang mempengaruhi kinerja karyawan. Karena masih banyak faktor-faktor lain yang mempengaruhi kinerja karyawan pada PT. Bakrie Construction, Bojonegara.

\section{UCAPAN TERIMAKASIH}

Pada penelitian ini saya mengucapkan terimakasih kepada Allah SWT yang telah memberikan rahmat dan kemampuan kepada saya untuk mewujudkan mimpi saya menjadi mahasiswa serta entrepreneur muda. Selanjutkan saya ucapkan terimaksih kepada kedua orangtua saya yang telah mendukung dan memberikan kasih sayangnya, serta dosen-dosen saya yang telah memberikan ilmu dan nasehatnya.

\section{DAFTAR PUSTAKA}


Prosiding The 1st National Conference on Applied Business, Education, \& Technology (NCABET)"

Unversitas Bina Bangsa 2021

DOI Article : 10.46306/ncabet.v1i1.37

Ananta Dwikristanto satedjo dan Sesilya Kempa. "Pengaruh Kompensasi dan Disiplin Kerja Terhadap Kinerja Karyawan PT. Modern Widya Tehnical Cabang Jayapura”. Vol. 5. No. (3). 2017.

Andrews, R., Boyne, G. A. 2010. Capacity, leadership, and organizational performance: Testing the black box model of public management. Public Adminis - tration Review, Vol $70(3): 443-454$.

Amir, F. M. “Memahami Evaluasi Kinerja Karyawan”. Jakarta: Mitra Wacana Media.

Ardana, I Komang, Ni Wayan Mujiati, I Wayan Mudiartha Utama. 2012. Manajemen sumber Daya Manusia. Edisi Satu. Cetakan Ke-1. Yogyakarta: Graha Ilmu.

Bandiera, O., Barankay, I., Rasul, I. 2007. Incentives for Managers and Inequality among Workers : Evidence from a Firm Level Experiment. Quarterly Journal of Economics 122, $729,773$.

Campbell, D. J., Campbell, J. M., \& Chia, H.B. (1998). Meritpay, performance appraisal, and individual motivation : ananalysis and alternative. Human Resource Managemen ,37 : $131-146$

Chhabra, T.N.(2001) : Human Resource Management, Conceptsand Issues, 2nd Revised Ed., Delhi : Dhanpat Rai \& Co.

Decenzo, David A. And Stephen P. Robbins (1999). Human Resource Management (6th). NewYork : John Wiley and Sons, inc.

Emron, E,. Dkk. (2016). “Manajemen Sumber Daya Manusia”. Cetakan ke-1. Bandung: Alfabeta.

Febiningtyas,R. E. R., Ekaningtias, D. 2014. The Effect of Leadership, Motivation and Work Discipline on the Employees 'Performance of Finance Section in the Regional Working Unit in Tulung Agung Regency. The Indonesian Accounting Review, Vol 4 (2) : 97 106. 